\title{
WATER CHEMISTRY AND BIOLOGY IN A SHALLOW LAKE (LAKE PAMVOTIS - GREECE). PRESENT STATE AND PERSPECTIVES.
}

\author{
KAGALOU I. ${ }^{\text {* }}$ \\ TSIMARAKIS G. ${ }^{2}$ \\ PASCHOS I. ${ }^{1}$
}

\author{
${ }^{1}$ Technological Educational Institute of Epirus \\ Dept. of Ichthyology-Fisheries - Lab. of Aqu. Ecosystems \\ P.O. BOX 152, 46100, Igoumenitsa, Greece \\ ${ }^{2}$ Municipal Enterprises of water and wastewater of loannina \\ El. Venizelou 4, Ioannina, 45444 Greece
}

* to whom all correspondence should be addressed tel: +30-6650-28130; fax: +30-6650-28131

Received: 04/05/01

Accepted: 20/12/01

\begin{abstract}
Lake Pamvotis is a shallow lake, located in NW Greece, which during last decades has influenced by a lot of man-made impacts such as sewage discharge, water level fluctuation, e.t.c. Water quality for physicochemical and biological parameters was monitored seasonally in five sampling-stations from April 1998 to March 1999. Lake Pamvotis is an eutrophic ecosystem which has been influenced by the nutrients input, rates of nutrient cycling and plankton-fish dynamics. According to the nitrogen: phosphorus ratio, the limiting factor is phosphorous during spring while a nitrogen limitation is switched on during the warm season. Restoration management strategy requires reduction of external organic load, control of non-point pollution from the surrounding agricultural area and establishment of biomanipulation techniques.
\end{abstract}

KEY WORDS: lake Pamvotis, eutrophication, water-quality, restoration, biomanipulation.

\section{INTRODUCTION}

Lake Pamvotis is a shallow lake (Koussouris et al., 1989; Margaris and Koussouris, 1990; Romero and Imberger, 1999; Stalikas et al.,1994) situated in Northwestern Greece. The lake which has been formed during the late miocene to the pliocene period (Aubouin, 1959) is an important ecosystem in the region It has a great recreational value and it is also supports local agriculture, tourism and fisheries. The lake has been stocked with fish annually since 1986 (Min. of Agricult., Dept. of Fisheries, Perf. of Ioannina). Some of the introduced fish species (Cyprinus carpio, Aristichtys nobilis), are zooplanktivorous (Varley, 1967; Paschos et al., 1995). During last decades, ecosystem of Pamvotis supported many activities such as irrigation, discharge of domestic sewages, sediment deposit, causing a serious problem in it's trophic state (Stalikas et al., 1994; Romero and Imberger, 1999; Ziogas et al., 1982) Cited by a mainly rural area, human impact to the lake is expressed first of all as eutrophication (Theochari and Papadopoulos, 1990; Romero and Imberger, 1999). Urban pollution comes from the city of Ioannina (pop. 100.000), laying along the southwestern shoreline. Moreover, agricultural efflu- 
ents of several smaller settlements and light industrial wastes from the surrounding area inflow the lake (Albanis et al., 1986; Stalikas et al., 1994). Eutrophication causes frequent algal blooms, depletion of dissolved oxygen and the rapid sediment accumulation, caused by high productivity, decreases the depth and enlarges the macrophyte zone (Sarika-Hatzinikolaou M., 1994).

Restoration of shallow eutrophic lakes can be more difficult than in deeper lakes because of the stronger interaction between the sediments and lake water (Bengtsson, 1975; Threlkeld, 1994). In shallow lakes internal loading can be a result of the build-up of pore water nutrients and subsequent release across the sediment-water interface even when the water column is oxygenated (Kleeberg et al., 1997).

Prior to the formulation of restoration strategies baseline monitoring is needed to assess the structure of the aquatic ecosystem (Heyman et al., 1984). As stated by many authors (Huttula and Nõges, 1998; Hutzar et al., 1998) abiotic and biotic parameters reflect the lake's trophic state. Also their assessment and their interrelationships may predict the effects of anthropogenic influences on ecosystem's health consisting of a fundamental "tool" for the effective management and restoration of lake water (Huttula and Nõges, 1998). For example, the seasonal variation of water quality parameters are seen in the lake ecosystem as drifts in hydrological, thermal, chemical and biological regimes (Huttula and Nõges, 1998). Nutrient availability, particularly of phosphorus (Schindler, 1977) determines potential phytoplankton biomass, while the grazing rate by zooplankton determine how much of this potential is realized (Carpenter, 1985). Zooplankton grazing is in turn influenced by the abundance of zooplanktivorous fish (Brooks and Dodson, 1965) and may be phytoplankton affected by trophic interactions that cascade from fish to phytoplankton (Carpenter, 1985; Kitchell, 1992).

Previous studies have been published concerning the physical, chemical and biological features of lake Pamvotis (Albanis et al., 1986; Koussouris et al., 1989; Margaris and Koussouris, 1990; Theochari and Papadopoulos, 1990; Andreadakis and Vasilopoulou, 1991; Stalikas et al., 1994; Paschos et al., 1995).

In the present study, water quality was monitored over 1-year period in order to gain a comprehensive view and establish a preliminary baseline condition of shallow and eutrophic lake Pamvotis.

The following physicochemical and biological data consist a part of an extended database (Albanis et al., 1999; Kagalou et al., 1999; Romero and Imberger, 1999) including metal concentrations in the water and the sediment of the lake, nutrients in the lake's sediment, BOD and COD concentrations, benthos abundance, fish abundance and meteorological data. The resulting database from the collected data, the seasonal dynamics and the interrelationships can assist in developing a management and restoration strategy.

\section{THE STUDY AREA}

Lake Pamvotis is located in the NW part of Greece, $\left(20^{\circ} 53 \mathrm{E}, 39^{\circ} 40\right)$ and is $\sim 470 \mathrm{~m}$ above sea level (Georgiadis et al., 2000). It's a shallow (mean depth $=4 \mathrm{~m}$ ) lake (Romero and Imberger, 1999) and occupies an area of $22.8 \mathrm{~km}^{2}$ (Albanis, 1986; Georgiadis, 2000). The total volume of water varies between $80 \times 10^{6}$ (summer) and $125 \times 10^{6}$ (winter) according to Albanis et al. (1986). The catchment area of lake Pamvotis (330 $\mathrm{km}^{2}$; Margaris and Koussouris, 1989) consists of two morphological units, i.e. a western mountainous unit and an eastern flat one (Aubouin, 1959). The basin has no naturally occurring surface outflows. The basin is recharged by karstic springs (Strouni, Krya, Touba) of the Mitsikeli anticline and the springs of Ag. Ioannis and Asphaka (Papadopoulos and Kitsaras, 1990). Two major drainage canals inflow the lake. Drainage from the basin occurs through a system of sink holes that drain to the rivers Arachthos, Louros and Kalamas (Papadopoulos and Kitsaras, 1990; Romero and Imberger, 1999). The present lake Pamvotis is the last and deeper remaining part of a larger lake covering the flat part of the basin which included two lakes separated by a peaty march: the lake Pamvotis and the ex-lake Lapsista which has been drained in $60 \mathrm{~s}$ and converted to agricultural land. From the geological point of view the hydrological basin consists of alluvial deposits, silicious material, clays, tertiary flysh, limestones, and dolomites. (Aubouin, 1959; Anagnostidis and Economou, 1980). The climate of the area is continental with cold wet winters $\left(<0^{\circ} \mathrm{C}\right)$ and hot dry summers $\left(>30^{\circ} \mathrm{C}\right)$. Annual precipitation (ca.1.1 1.2 $\mathrm{m}$ ) roughly matches lake 


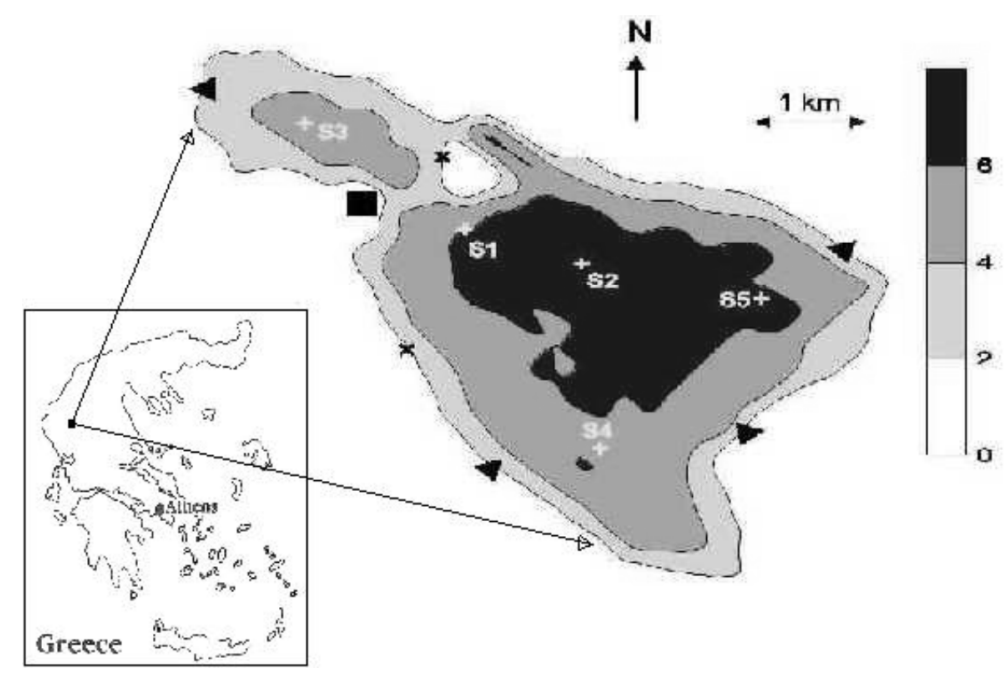

Figure 1. Bathymetry of lake Pamvotis (Greece) with the 5 sampling-stations, shown as + . Locations of inflows and outflows given by $\nabla$ and the city of Ioannina demarcated by $\square$.

surface evaporation. Interannual variability of precipitation is high with a range of $0.7 \sim 1.5 \mathrm{~m}$. Periods with reductions in rainfall are caused by changes in the atmospheric circulation over the Mediterranean (Bartzokas and Metaxas, 1995).

\section{MATERIALS AND METHODS}

Water samples were collected bi-weekly from April 1998 to March 1999, in five sampling-stations, using a Hydro-Bios water sampler of 21 capacity (Figure 1). Sites were selected to represent different hydrodynamic environment and different distances from pollution sources. Water samples were taken at three depths, surface (ca. $0.3 \mathrm{~m}$ ), bottom (ca. $0.5 \mathrm{~m}$ ) above bottom and middepth for physicochemical analysis and in two depths (surface, bottom) for phytoplankton and zooplankton determination. At least 21 and 101 of water were sampled for phytoplankton and zooplankton, respectively (APHA, 1985; Moustaka and Tsekos, 1989; Michaloudi et al., 1997). Analytical procedures were used for the chemical analysis, according to APHA (1985). Temperature and $\mathrm{pH}$ were measured using a thermometer and pHmeter (WTW type). Water transparency was estimated using a Secchi disk. Samples for phytoplankton analysis after their pretreatment were counted according to Ulterhmol's method and grouped into larger taxonomic groups (cyanophytes, chlorophytes, diatoms). The determination of phytoplankton biomass (wet weight) was based on the estimation of the volume of each species, assuming a specific gravity of one (Edler, 1979).

Samples for the identification of zooplankton, were stored in a $6 \%$ formaldelyde sol. until microscopic-stereoscopic counting was performed. Three zooplankton groups were identified: copepods, cladocerans and rotifers (Alden et al., 1982; APHA, 1985).

Monthly average values, from the bi-weekly sampling for the three depths, were used to describe the seasonal variations and the vertical profile of the examined parameters.

\section{RESULTS}

The surface water temperatures varied from $6.0^{\circ} \mathrm{C}$ (in January) to $27.1^{\circ} \mathrm{C}$ (in July) and bottom temperatures followed the same variation (i.e. from $5.89^{\circ} \mathrm{C}$ in January to $26.8^{\circ} \mathrm{C}$ in July, Table 1) A weak thermal stratification was noticed from April through August while the water mixing began early in September. The lake's mixing regime is polymictic.

Dissolved oxygen in surface waters fluctuates between $5.3 \mathrm{mg} \mathrm{l}^{-1}$ and $11.9 \mathrm{mg} \mathrm{l}^{-1}$, appearing the minimum values through the warm period (Table 1). Diurnal stratification was measured throughout the spring and summer, while the water column was isothermal in winter (Table 1). The maximum concentration, $11.9 \mathrm{mg} \mathrm{l}^{-1}$ was recorded in January during the isothermal conditions. Decomposition processing and sediment oxygen demand were sufficient to cause lower D.O. val- 
Table 1. Physical-Chemical data of lake Pamvotis (a:surface, b:mid-depth,c:bottom)

\begin{tabular}{|c|c|c|c|c|c|c|c|c|c|c|c|c|c|}
\hline Month & & $\mathbf{A}$ & M & $\mathbf{J}$ & $\mathbf{J}$ & A & $\mathbf{S}$ & O & $\mathbf{N}$ & D & $\mathbf{J}$ & F & M \\
\hline Temp. & $\mathbf{a}$ & $14,1+0.2$ & $18,3+0.4$ & $23,9+0.58$ & $27,1+0.25$ & $26,1+0.14$ & $23,4+0.14$ & $18,6+0.14$ & $11,2+0.25$ & $7,9+0.06$ & $6.0+0.04$ & $6,4+0.3$ & $11,8+0.4$ \\
\hline \multirow[t]{2}{*}{$\left({ }^{\circ} \mathrm{C}\right)$} & b & $13,8+0.1$ & $17,6+0.11$ & $22,3+0.38$ & $26,8+0.30$ & $26.0+0.09$ & $23,2+0.13$ & $18,5+0.11$ & $11,1+0.21$ & $7,7+0.04$ & $5,8+0.07$ & $6,1+0.05$ & $10,6+0.18$ \\
\hline & c & $12,9+0.57$ & $17,3+0.12$ & $21,2+0.21$ & $24,9+0.47$ & $25,9+0.18$ & $23,1+0.10$ & $18,4+0.07$ & $11.0+0.19$ & $7,7+0.03$ & $5,6+0.04$ & $5,8+0.05$ & $9,5+0.17$ \\
\hline \multirow[t]{3}{*}{$\mathrm{pH}$} & $\mathbf{a}$ & $7,7+0.19$ & $8,2+0.06$ & $7,8+0.07$ & $7,5+0.02$ & $8,7+0.04$ & $8,5+0.08$ & $8,4+0.09$ & $8,2+0.02$ & $8.0+0.01$ & $8,4+0.02$ & $8,5+0.02$ & $8,2+0.02$ \\
\hline & b & $7,9+0.11$ & $8,2+0.05$ & $7,8+0.09$ & $7,5+0.03$ & $8,7+0.06$ & $8,5+0.09$ & $8,4+0.07$ & $8,2+0.02$ & $8.0+0.02$ & $8,4+0.03$ & $8,5+0.02$ & $8,1+0.10$ \\
\hline & c & $7,5+0.13$ & $8.0+0.06$ & $7,1+0.05$ & $7,1+0.16$ & $7,1+0.17$ & $8,4+0.06$ & $8.0+0.13$ & $8,2+0.02$ & $7,9+0.01$ & $8,3+0.03$ & $8,4+0.01$ & $7,9+0.04$ \\
\hline D.O & $\mathbf{a}$ & $10+0.08$ & $8.0+0.07$ & $7,8+0.20$ & $8.0+0.23$ & $6,6+0.75$ & $5,3+0.37$ & $6,8+0.54$ & $7,5+0.13$ & $8,7+0.17$ & $11,9+0.40$ & $10,6+0.05$ & $9,6+0.06$ \\
\hline \multirow[t]{2}{*}{$\left(\mathrm{mg} \mathrm{l}^{\mathbf{l}^{-1}}\right)$} & b & $9,6+0.10$ & $7,8+0.04$ & $6,2+0.48$ & $7,6+0.40$ & $6.0+0.35$ & $4,3+0.19$ & $6,4+0.42$ & $7,4+0.13$ & $8,5+0.12$ & $12.0+0.49$ & $10,7+0.06$ & $9,4+0.14$ \\
\hline & c & $8,2+0.49$ & $7.0+0.51$ & $3,6+0.51$ & $4,1+0.65$ & $4,9+0.93$ & $3,8+0.23$ & $5.0+0.50$ & $7,3+0.14$ & $8,5+0.13$ & $11,5+0.39$ & $10,3+0.14$ & $8,3+0.14$ \\
\hline $\begin{array}{l}\text { Secchi d. } \\
\text { (m) }\end{array}$ & & 0,7 & 0,7 & 0,6 & 0,6 & 0,5 & 0,5 & 0,6 & 0,8 & 0,8 & 0,9 & 0,8 & 0,7 \\
\hline
\end{tabular}

ues, near-bottom, from June to October relatively to other depths.

The $\mathrm{pH}$ fluctuated between 7.5 and 8.7 in surface waters appearing lower values in June and July (Table 1). $\mathrm{pH}$ values above the sediment ranged between 7.5 and 8.4. Similar to temperature and dissolved oxygen, stratification of $\mathrm{pH}$ occurred during the warm period.

Secchi-disk transparency varied between 0.5 and $0.9 \mathrm{~m}$ (Table 1). The highest values (Nov., Dec., Jan.) may be related to the low phytoplankton biomass, while there was low seasonal variability throughout the year. Factors which favor the turbid water state in lake Pamvotis are the algal biomass and the stirring-up of the sediment after wind events and heavy rainfalls. Moreover boat activity taking place in the lake enhances resuspension of the sediment (Margaris and Koussouris, 1990; Cooke et al., 1993).

Concentrations of soluble reactive phosphorous (SRP) had a seasonal range of $0.06 \sim 0.35 \mathrm{mg} \mathrm{P} \mathrm{l}^{-1}$, in surface water and exhibited higher values during the warm-dry period. Maximum value was recorded in September while high values were also observed during Dec-Jan. The near-bottom SRP profile shows a quite similar seasonal pattern, appearing the highest values during Aug.Sept. (Figure 2). SRP concentrations are probably influenced by inflows, algal dynamics and internal loading. During the periods of high water level, due to the inflows (Dec. to Jan.) large amounts of phosphorous are entering the lake. During warm period D.O. and $\mathrm{pH}$ conditions (see Table 1) in the sediment-water interface enhance the internal loading process, enriching the water column with phosphorus from the sediment. (Bengston, 1975) This fact, in relation to the low water level, results in high concentrations of SRP. Nitrate-Nitrogen had a number of maxima and minima through the monitoring year exhibiting higher concentrations during spring and winter (Figure 2). The higher values in the wet period varied between 0.22 and $1.16 \mathrm{mg} \mathrm{l}^{-1}$, and may be attributed to the Nitrogen inputs from the inflows. During summer, lower concentrations, ranging from 0.34 to $0.71 \mathrm{mg} \mathrm{l}^{-1}$, is probably the result of biological utilization.

Elevated ammonia-nitrogen concentrations, caused by the inflows, were observed during the wet period resulting in a maximum value of 0.34 $\mathrm{mg} \mathrm{l}^{-1}$ in February (Figure 2). Near-bottom, the highest value was recorded in August $\left(0.41 \mathrm{mg} \mathrm{l}^{-1}\right)$ probably caused by the decomposition of organic matter in the sediment-water interface.

Concentrations of silica, ranged between 3.33 and $14.99 \mathrm{mg} \mathrm{l}^{-1}$ in the whole water column, appearing the lower values in surface water (Figure 2). Higher concentrations were observed from May to November.

The seasonal pattern of Chlorophyll-a (Chla) is present in Figure 3. The average concentrations of Chla were ranged between 13 49 $\mathrm{mg} \mathrm{m}^{-3}$ reflecting the eutrophic state of the lake (Volleinweider, 1968; OECD, 1982; Margaris and Koussouris 1990).

Higher concentrations were observed during JulyAugust (26.4-58.3 mg m $\mathrm{m}^{-3}$ ), Sep.-Oct. (10.7-64.2 $\mathrm{mg} \mathrm{m}^{-3}$ ) and Jan. (5.1-30.6 $\left.\mathrm{mg} \mathrm{m}^{-3}\right)$. Vertical differences in Chla concentrations were marked during the limited stratification period. 

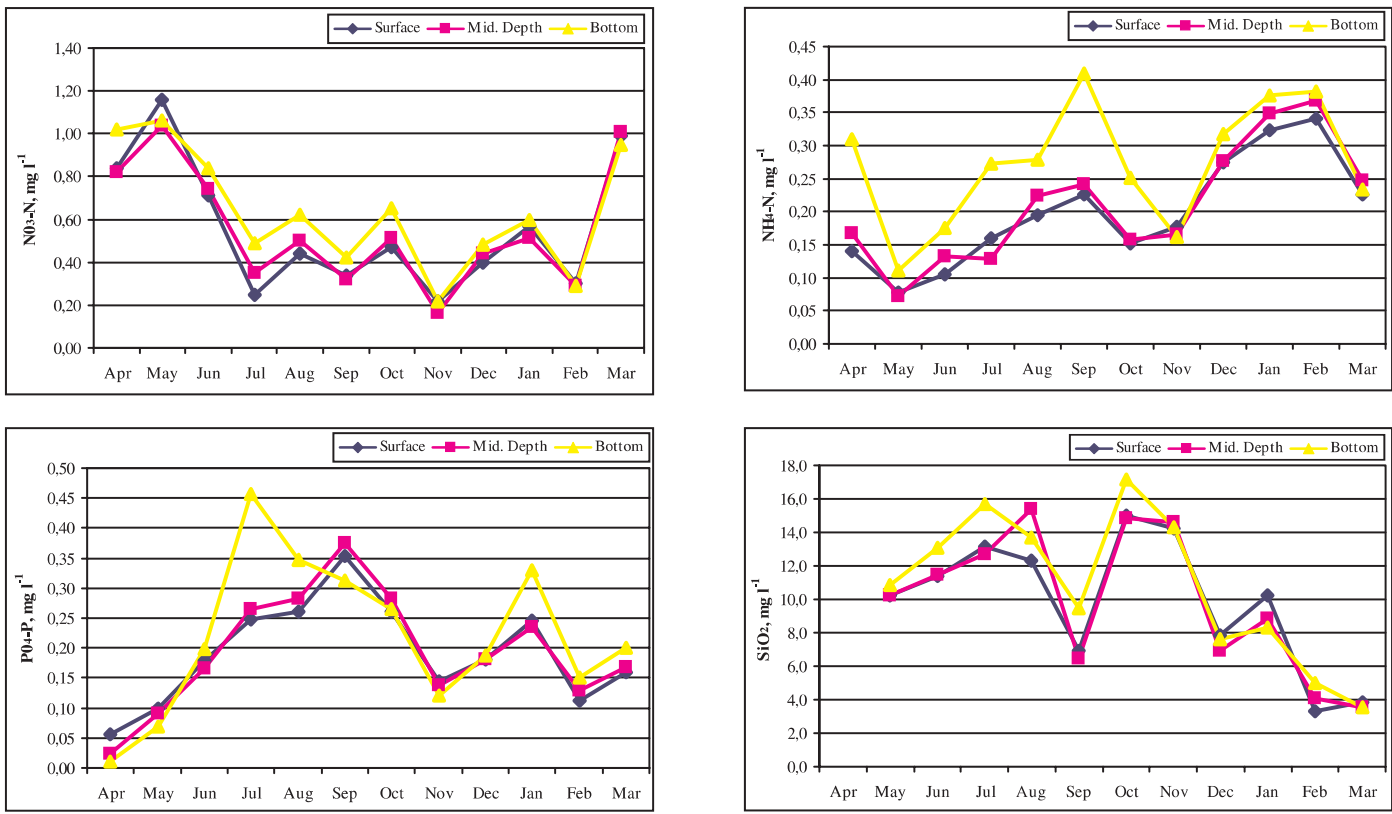

Figure 2. Seasonal distributions of nutrients $\left(\mathrm{mg} \mathrm{l}^{-1}\right)$, in the three depths.

During the winter period the near-bottom Chla was generally greater than at the surface and this may be due to the sedimentation of the large size phytoplanktonic organisms which dominated during this period. Otherwise vertical differences were minimal over the monitoring period.

The annual succession of algae in Lake Pamvotis was: chlorophytes and diatoms in the spring,
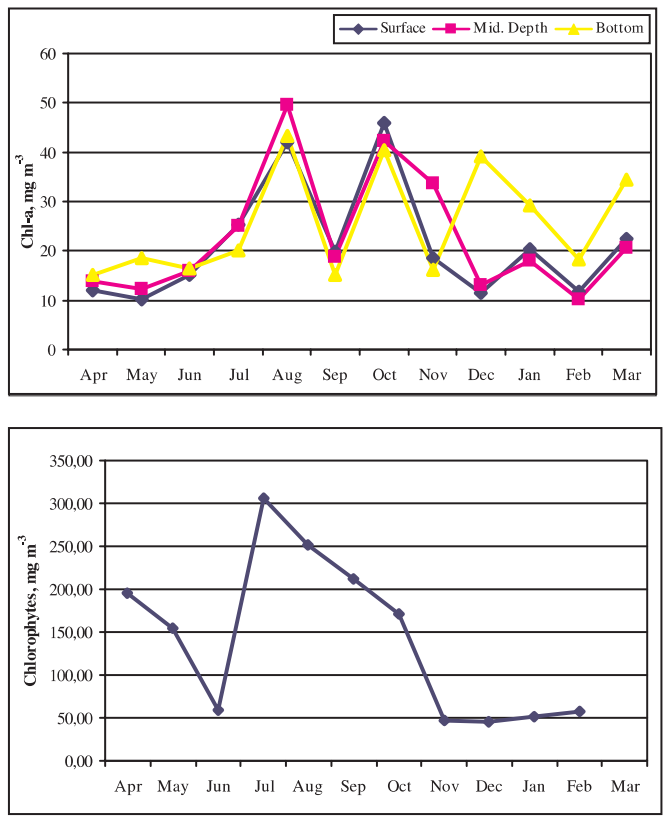

chlorophytes in early-summer, cyanophytes in late-summer and diatoms in autumn and winter (Figure 3). Cyanophytes in Lake Pamvotis start their seasonal growth in response to the nitrogen depletion when phosphorus is available. In the spring-winter period when high concentrations of nitrogen are present, cyanophytes, as nitrogenfixing algae, had no advantage over other algal
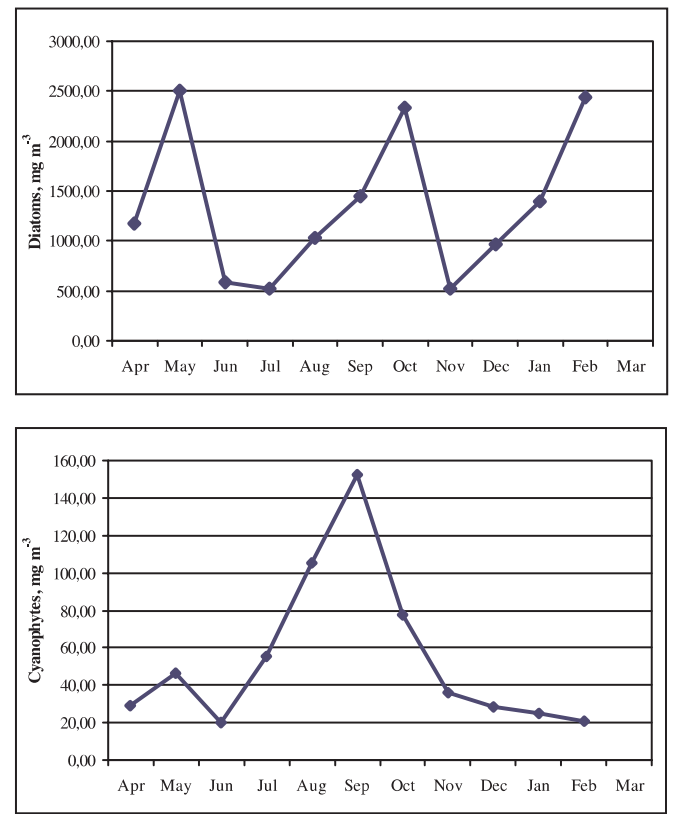

Figure 3. Monthly fluctuations of Chl-a $\left(\mathrm{mg} \mathrm{m}^{-3}\right)$ and algal biomass $\left(\mathrm{mg} \mathrm{m}^{-3}\right)$. 


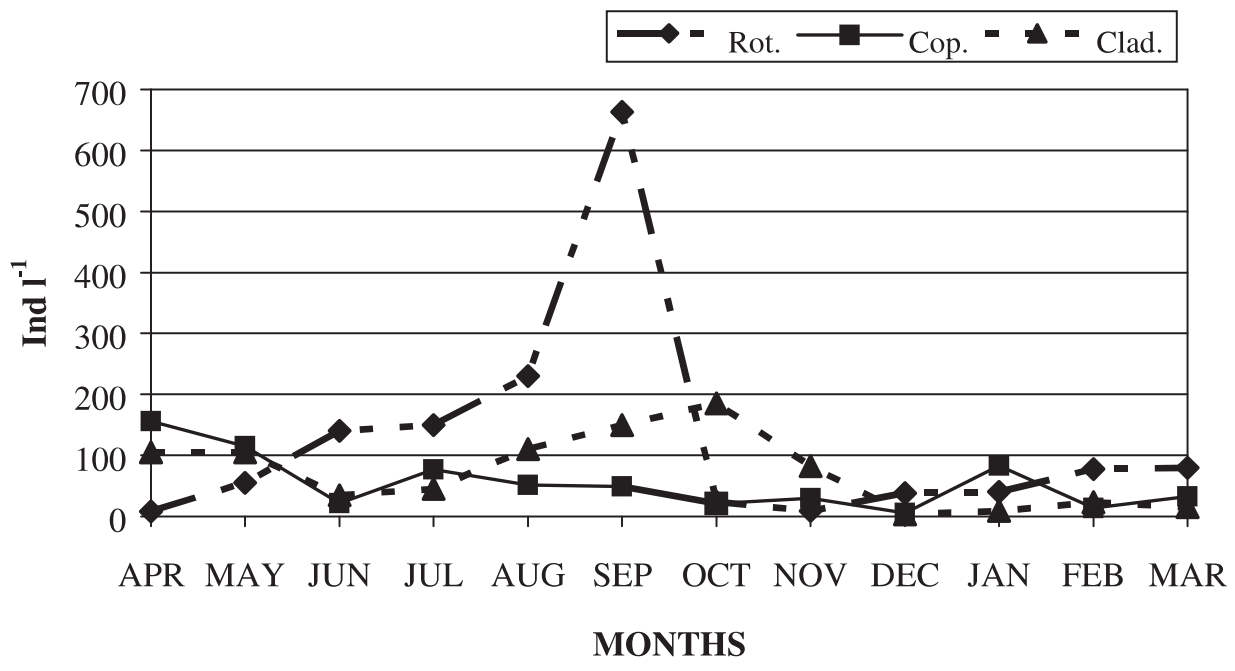

Figure 4. Monthly fluctuations of zooplankton abundance (ind $\mathrm{l}^{-1}$ ).

species and their abundance remained low. The chlorophytes maxima were observed in July. The group's biomass revealed a positive correlation with temperature and a slight negative one with ammonium-nitrogen $(\mathrm{r}=0.44, \mathrm{n}=95, \mathrm{p}<0.05$ and $\mathrm{r}=-0.13, \mathrm{n}=95, \mathrm{p}<0.1$, respectively). The annual cycle of diatoms showed quite stable trends with two major peaks: one in early spring and the second one in autumn. Populations of diatoms declined rapidly in May.

The temporal sequence of the zooplankton was copepods and cladocerans in the spring, rotifers in the summer and cladocerans during autumn and winter (Figure. 4). Higher copepod abundance was noticed during April-May (average 100 156 ind. $1^{-1}$ ).

Rotifers started to grow at the end of spring and their population reached an abundance of 600 ind. $1^{-1}$ in September. Their population is controlled by the two other groups due to the increased grazing pressure. High abundance of cladocerans and copepods occurs in April and May due to their reproduction period, early spring.

\section{DISCUSSION}

Trophic state of the lake, nutrients, external loading

Quantitative responses of the biota to the increased nutrient loading are adequate in a nutrient-limited environment but can differ in a wide range in the case of other limitations (Huttula and Nõges, 1998).
According to nutrients and chlorophyll-a concentrations Lake Pamvotis is classified as eutrophic lake (Vollenweinder, 1968; OECD, 1982; Vollenweinder and Kerekes, 1982; Straskraba and Tundisi, 1999). According Chlorophyll-a values given by Koussouris et al. (1989), Lake Pamvotis showed eutrophic conditions based on the OECD classsification. The ratio of DIN/SRP (where $\mathrm{DIN}=\mathrm{NO}_{3}^{-}+\mathrm{NH}_{4}^{+}, \mathrm{NO}_{2}^{-}$was found negligible) reflects the limiting factor, controlling the primary production. In our case, this ratio was greater than the Redfield ratio of 16 , which is the ideal ratio for algal growth (Straskraba and Tundisi, 1999), during the period April-May, suggesting a P-limitation (the ratio ranged between 4-130 with a mean value of 24). During the warm period (Jun.-Sept.), low water level, internal Ploading process enriches the water more with phosphorus than with nitrogen. As a result, nitrogen limitation is switched on (mean value of the ratio, 3 and range 1-10). In winter (Nov.-Mar.) the ratio ranged between $2-17$ with a mean value of 5 , thus showing that nitrogen rather than phosphorus could have been the main nutrient limiting factor.

Nutrient data, from 1990s (Koussouris et al., 1989; Andreadakis and Vasilopoulou, 1991) illustrate the trophic state of the lake, over a period of 10 years. It is clear that the increase of eutrophication process is attributed to the sewage discharge into the lake, the point-pollution sources along the lake-shore and the agri- 
cultural diffuse pollution.(Albanis et al., 1986). After the operation of the sewage treatment unit, at 1990s and the removal of some point pollution sources (as industries, poultries etc.), reduction of P-loading led to the improvement of water quality. According Koussouris et al. (1989) the surface phosphorus loading during the period $1985-88$ was $1.07 \mathrm{~g} \mathrm{~m}^{-2} \mathrm{y}^{-1}$. Following the same methodology proposed by Koussouris et al. (1989) and further by Dillon and Rigler (1975) and using the last hydrological data from Papadopoulos and Kitsaras (1990); Romero and Imberger (1999), it was found that the surface phosphorus loading during 1998-99 was $0.66 \mathrm{~g}$ $\mathrm{m}^{-2} \mathrm{y}^{-1}$ (assuming that the annual outflow for the above period was $\mathrm{Q}=101 \times 10^{6} \mathrm{~m}^{3}$ and $\mathrm{z}(\mathrm{avg})=$ $4 \mathrm{~m}$. Romero and Imberger, 1999). Moreover maximum chlorophyll-a values have declined about five times since 1989 (Koussouris et al., 1989). Further nutrient reduction minimizing the point loading, is required to convert the present eutrophication status in a lower trophic status.

For this reason, it is possible that practices as, nutrients sedimentation through a system of sediment basins could reduce the external loading (Huttula and Nõges, 1998). Nutrients losses from the diffuse pollution are influenced by a large number of factors as climate, soil characteristics, hydrology, land management (Cooke et al., 1993). In Lake Pamvotis, the understanding of the behavior of nitrogen and phosphorus in the whole system is yet incomplete, in order to apply an effective nutrient management.

On the other hand, tasks concerning the decrease of fertilization intensity and the re-organizing of irrigation system could be included in the future water management policy.

\section{Plankton dynamics and biomanipulation scenarios}

According to Reynolds (1984), the influence of various factors on the seasonal appearance of phytoplankton differs in significance with physical factors (temperature, etc.) being the most important and chemical (nutrient level) as well as biotic factors (grazing) being of lesser importance.

As it was mentioned above, in lake Pamvotis during the spring period (Apr.,May) a P-limitation occurs and during the warm period (June to September), N-limitation occurs and nitrogen-fix- ing species (most of the cyanophytes algae) get the advantage in competition. Tilman, (1986) suggests that many cyanophytes species are good competitors for nitrogen but poor competitors for phosphorus. Among physical factors which may supply an advantage for cyanophytes, the low light availability occurring during the warm season in the lake seems to enhance their growth (Mur, 1978). During this period, Secchi depths fluctuated between $0.5-0.6 \mathrm{~m}$.

According Tilman (1986), chlorophytes increase under high temperatures and dominate in lakes where nitrogen, silicon or light are limiting for growth. In our study, the group's biomass revealed a positive correlation with temperature and a slight negative one with ammonium-nitrogen probably because ammonium is, energetically, the most favorable source of combined inorganic nitrogen (Reynolds, 1984). The Secchi disk transparency, in Lake Pamvotis, was recorded quite low during the period of chlorophyte growth. Kagalou and Petridis (2001) using the redundancy analysis, performed by the CANOCO statistical software found that temperature is a main factor in producing effects on cyanophytes and chlorophytes abundance in lake Pamvotis. Heavy rainfalls and the turbulence effects enhance the distribution of diatoms during their peak appearance (Feb., Oct.), since their decline is also due to the sedimentation when these phenomena are absent. Grazing could also influenced diatoms abundance since the rotifers population in June and July ranged between 600-800 ind. ${ }^{1-1}$. High concentrations of Silica during July, August and January seemed to be important for their growth (Bailey-Watts, 1976). Seasonal succession of algae in Lake Pamvotis is a complicated succession, as it happens in many shallow, productive lakes (Hutchinson, 1967). This sequence differs from the pattern of other eutrophic Greek lakes (Moustaka, 1993; Moustaka and Tsekos, 1989; Tryphon and Moustaka, 1997) and may be attributed to the shallowness of the lake and to the weakness of thermal stratification.

The structure and the annual variation of zooplanktonic community suggests the eutrophic state of the lake. Considering past data on zooplankton (Paschos et al., 1995) it seems to be a decrease in zooplankton abundance. Temperature, food conditions and competition affect their seasonal variability. 
Moreover, it seems to exist a predation pressure by zooplanktivorous fish (such as Carrasius auratus, Cyprinus carpio, Aristichthys nobilis, Rutilus rubilio according Varley, 1967) on zooplankton community. Regarding to data obtained during the monitoring period (from two fish surveys) there is a higher biomass of zooplanktivorous species, i.e. $112.15 \mathrm{~kg}$ corresponding to a total abundance (juvelines and adults) of 287 individuals than the biomass of piscivorous species, i.e $18.7 \mathrm{~kg}$ corresponding to a total abundance of 7 individuals (Romero and Imberger, 1999; Kagalou et al., 1999). This results to a reduced grazing effect on algal biomass and further to a non-effective eutrophication control. According to biomanipulation theory (Perrow, 1997) the increase of ratio piscivore/zooplanktivore fish populations could reduce the zooplanktivores community increasing the herbivorous zooplankton population. In Lake Pamvotis, according to these fish surveys the piscivore/zooplanktivore ratio is equal to 0.16 . Experiments involving fish manipulation indicate that if predation pressure on zooplankton is reduced, the capacity of zooplankton to control phytoplankton will be especially high in shallow lakes (Lammens et al., 1990).

Concerning lake Pamvotis, food-web manipulation, through biomanipulation techniques, as topdown control, may be contribute to the control of the excess algal biomass and to convert the present turbid water phase to a high clarity phase. For this reason further fish population dynamic data need as well as qualitative and quantitative re-estimation of the introduced species (during the fish stocking projects) in order to increase the piscivore/zooplanktivore ratio. A large number of shallow lakes have responded favorably to biomanipulation techniques (Perrow, 1997; Drenner and Hambright, 1999). Jeppesen et al. (1997) suggested that although fish manipulation methods still need to be on further development they will undoubtedly become an important lake restoration tool, especially in the case of shallow lakes.

\section{CONCLUSIONS}

In this study, a preliminary baseline limnological condition of the shallow, eutrophic Lake Pamvotis is provided. Initial restoration efforts were focused on removal of point-pollution sources. The philosophy of new management and restoration plan should be aim at the reduction of the external organic load, the control of diffuse pollution coming from the agricultural area and the biomanipulation process. This multi-strategy approach requires new management "tools" as long - term monitoring data, hydrodynamic and ecological modeling in order to find out possible coeffects, to understand and predict the behaviour of the lake's ecosystem. By this means, it is possible to assess protective measures, to maintain the water quality and even to restore the lake.

\section{ACKNOWLEDGEMENTS}

The authors are very grateful to Dr. K. Hatzibiros, National Technical University of Athens, for his valuable comments on the manuscript. Financial support for the study was provided by the Municipality of Ioannina and the Onassis Benefit Foundation.

\section{REFERENCES}

Albanis, T., Pomonis, P. and Sdoukos, A. (1986), Seasonal fluctuations of organochlorine and triazines pesticides in the aquatic system of Ioannina basin (Greece), The Sc. of the Tot. Env. 58, 243-253.

Albanis, T., Galani, A. and Giannoulis, N. (1999), Evaluation of Restoration methods of Lake Pamvotis, Final Proj. Report., Univ. of Ioannina, Ioannina, Greece.

Alden, R.W., Dahiga, R.C. and Young, R.J. (1982), A method for the enumeration of zooplankton samples, J. Exp. Mar. Biol. Ecol. 59, 185.

Andreadakis, A. and Vasilopoulou, M. (1991), Mathematical modeling of the water quality characteristics of Lake Pamvotis, In: Proceedings of the II Conference on Environmental Science and Technology, 423-432, Lesbos, Greece.

Aubouin, J. (1959), Contribution à l'étude géologique de la Grèce Septentrionale. Les confines de l'Epire et de la Thessalie, Ann. Geol. d. Pays Helen. 10, 1-525, Athènes.

Anagnostidis, K. and Economou, A. (1980), Limnological studies of Lake Pamvotis (Ioannina) Greece, Arch. Hydrobiol. 89, 313-342.

APHA, (1985), Standard Methods for the examination of water and wastewater, $16^{\text {th }}$ Edition, Washington. 
Bailey-Watts, A.E (1976), Planktonic diatomes and some diatom silica relations in shallow eutrophic Scottish loch, Freshwat. Biol. 6, 69-80.

Bartzokas, A. and Metaxas, D.A. (1995), Factor Analysis of some climatological elements in Athens, Theoretical and applied climatology, 52, 195-205.

Bengtsson, L. (1975), Phosphorus release from a highly eutrophic lake sediment, Verh. Int. Ver. Limnol. 19, 1107-1116.

Brooks, J.L. and Dodson, S.I. (1965), Predation, bodyzize and composition of plankton, Science, 150, 28-35.

Carpenter, S.R. (1991), Patterns of primary production and herbivory in 25 North American lake ecosystems, In: J. Cole et al. (eds), Springer, USA.

Cooke, G.D., Welch E.B., Petersen, S.A. and Neuroth, P.R. (1993), Restoration and Management of lakes and reservoirs, Second Edition, Lewis Publish. USA.

Dillon, P.J. and Rigler, F.H. (1975), A simple method for predicting the capacity of lake for development based on lake trophic status, J. Fish Res. Board. Can. 32, 1519-1531.

Drenner, R.W. and Hambright, K.D. (1999), Biomanipulation of fish assemblages as a lake restoration technique, Arch. Hydrobiol. 146, 129-165.

Edler, L. (1979), Recommendations for marine biological studies in the Baltic sea, Rep. of UNESCO Working Group 11, Marine Biologists, National Swedish Env. Protection Board, Stockholm.

Georgiadis, Th., Artelari, P., Chondropoulos V., Kaspiris, P. and Legakis, A. (2000), Natura biotopes, Proj. Report, Univ. of Patras, Univ. of Athens, Greece.

Heyman, U., Ryding, S.V. and Forsberg, C. (1984), Frequency distribution of water quality variable, Water Res. 18, 787-794.

Huszar, V.L. and Caraco, N. (1998), The relationship between phytoplankton composition and physical-chemical variables, Freshwater. Biol. 40, 679-696.

Hutcinson, G.E (1967), A Treatise on limnology, Vol. II. John Wiley \& sons, New York.

Huttula, J. and Nõges, J. (1998), Present state and future fate of Lake Vortsjary, In: Finnish-Estonian Report: The Finnish Environment, Tampere, Finland.

Jeppesen, E., Jensen, J., Sondergraad, M. and Lauridsen T. (1997), Top-down control in freshwater lakes: the role of nutrient state, sumberged makrophytes and water-depth, Hydrobiologia, 342/343, 151-164.

Kagalou, I., Paschos, Y. and Natsis, L. (1999), Evaluation of Restoration methods of Lake Pamvotis, Fin. Report, Municip. Comp. of Lake Pamvotis, Ioannina.

Kagalou, I. and Petridis, D.(2001), Seasonal variations of water quality parameters in a shallow lake (Lake Pamvotis) and effects on phytoplankton, zooplankton communnities, Hydrobiologia, (submitted for publicaation).

Kitchell, J.F. (1992), Food web management: A case study of Lake Mendota, Springer, USA.

Kleebery, A. and Kozerski, H.P. (1997), Phosphorus release in Lake Grosser Muggelsee and its implications for lake restoration, Hydrobiologia, 342, 9-26.

Koussouris, T.S., Diapoulis, A.C. and Photis, G.D. (1989), Evaluating the trophic status of a shallow polluted lake, Lake Ioannina, Greece, In: $5^{\text {th }}$ International Symposium on Environmental pollution and its impact on life in the Mediterranean region, MESAEP (eds), FRG.

Lammens, E.H., Gulati, D., Meiijer, M. and Van Donk, E. (1990), The first biomanipulation Conference: A synthesis, Hydrobiologia, 200/201, 619-627.

Margaris, N. and Koussouris, Th. (1990), Restoration of lake Pamvotis, Proj. Report, Lesbos, Greece (in Greek).

Michaloudi, E., Zarfjian, M. and Economides, P.S. (1997), The zooplankton of Lake Mikri Prespa, Hydrobiologia, 351, 77-94.

Moustaka-Gouni, M. (1993), Phytoplankton succession and diversity in a warm monomictic, relatively shallow lake: Lake Volvi, Macedonia, Greece, Hydrobiologia, 249, 33-42.

Moustaka-Gouni, M. and Tsekos, I. (1989), The structure and dynamics of the phytoplankton assemblages Lake Volvi, Greece II. Phytoplankton biomass and environmental factors, Arch.Hydrobiol. 115, 575-588.

Mur, L.R. (1999), Growth kinetics of some cyanobacteria. In: Proc. of the symp. Eutrophication Research, Wageningen, The Netherlands.

OECD (1982), Eutrophication of Waters. Monitoring, Assessment and Control, OECD, Paris.

Papadopoulos, F. and Kitsaras, L. (1990), The Lake of Ioannina "Pamvotida" Master Thesis, Democritos Univ. of Thrace, Xanthi, Greece (in Greek).

Paschos, Y, Kagalou, I. and Natsis, L. (1995), A management study of Lake Pamvotis, Municip. Comp. of Lake Pamvotis, Ioannina, Greece (in Greek). 
Perrow, M. (1997), Biomanipulation in shallow lakes: state of the art, Hydrobiologia, 342/343, 355-365.

Pijanowska, J. and Prejs, A. (1997), Food-web manipulation in shallow, eutrophic lakes, Hydrobiologia, 342/343, 305-310.

Reynolds, C.S. (1984), Phytoplankton periodicity-interactions of form, function and enviromental variability, Freshwater. Biol. 14, 111-142.

Romero, J. and Imberger, J. (1999), Lake Pamvotis Project, Fin. Report, Centre for Water Research, Univ. of W. Australia, Perth, W. Australia.

Sarika-Hatzinikolaou, M. (1994), Floristic and phytosociological study on aquatic ecosystem of Epirus (NW Greece), Ph.D Thesis, Dept. of Biology, Univ. of Athens, Greece.

Schindler, D.W. (1997), The evolution of phosphorus limitation in lakes, Science, 195, 260-262.

Stalikas, C., Pilidis, G. and Karayannis, M. (1994), Heavy metal concentrations in sediments of Lake Pamvotis and Kalamas River in North-Western Greece, Fres. Environ.Bull. 3, 575-579.

Straskraba, M. and Tundisi, J.G. (1999), Guidelines of lake management (Vol.9), International lake Envir. Committee, Japan.

Theochari, V. and Papadopoulos, G. (1990), Contribution à l'étude des phenomenes de l'eutrophisation du lac de Ioannina, Thalassographica, 13, 55-70.

Threlkeld, S.T. (1994), Benthic-pelagic interactions in shallow water columns: and experimentalist's perspective, Hydrobiologia, 275/276, 293-300.

Tryphon, E. and Moustaka-Gouni, M. (1997), Species composition and seasonal cycles of phytoplankton with special reference to the nanoplankton of Lake Mikri Prespa, Hydrobiologia, 351, 61-75.

Tilman. D. (1986), Green, blue-green and diatom algae: Taxonomic differences in competitive ability for phosphorus, silicon and nitrogen, Arch. Hydrobiol. 106, 473-485.

Utermohl, H. (1958), Zur Vervollkommnung der quantitativen Phytoplankton-Methodik. - Mitt. int. Ver. theor. angew. Limnol. 9, 1-38.

Varley, M.E. (1967), British Freshwater Fishes, Fishing New Books (eds), London.

Vollenweider, R.A. (1968), Scientific Fundamentals of the Eutrophication of lakes and flowing waters with particular reference to nitrogen and phosphorus as factors in Eutrophication, OECD, Paris.

Vollenweider, R.A. and Kerekes, J. (1982), Eutrophication of Waters. Monitoring, Assessment and Control, OECD, Paris.

Ziogas, G., Stamoulakis, G., Kostantis, C. and Kalfakakou, V. (1982), The pollution and the environmental problems in the basin of Ioannina, Techn. Report T.E.E, Ioannina(in Greek). 